Artikel Penelitian

\title{
Formulasi Biskuit Rendah Indeks Glikemik (BATIK) Dengan Subtitusi Tepung Pisang Klutuk (Musa balbisiana Colla) dan Tepung Tempe
}

\section{Formulation Low Glycemic Indeks Biscuit using Banana and Tempe Flour}

Ika Heri Kustanti, Rimbawan, Leily Amalia Furqon.

Departemen Gizi Masyarakat, Fakultas Ekologi Manusia, Institut Pertanian Bogor, Bogor.

Korespondensi dengan penulis (ikaherikustanti@gmail.com)

Artikel ini dikirim pada tanggal 28 Agustus 2016 dan dinyatakan diterima tanggal 30 November 2016. Artikel ini juga dipublikasi secara online melalui www.jatp.ift.or.id. Hak cipta dilindungi undang-undang. Dilarang diperbanyak untuk tujuan komersial.

Diproduksi oleh Indonesian Food Technologists $® @ 2017$

\section{Abstrak}

Penatalaksanaan diet bagi penderita diabetes mellitus (DM) dilakukan dengan pengaturan pola makan untuk mengontrol kadar glukosa darah. Konsep Indeks Glikemik (IG) merupakan pendekatan yang dapat digunakan untuk memilih pangan yang baik dalam pengelolaan kadar glukosa darah. Salah satu bahan pangan lokal yang berpotensi untuk dapat digunakan sebagai pengganti terigu dan memiliki IG rendah adalah pisang (46-51). Biskuit juga disubtitusi dengan tepung tempe karena tepung tempe mempunyai nilai IG yangan relatif rendah. Penelitian ini bertujuan untuk memformulasi biskuit rendah IG dengan substitusi tepung pisang dan tepung tempe sebagai salah satu alternatif pangan bagi diabetic. Tepung pisang klutuk dipilih karena masih pemanfaatannya masih terbatas. Rancangan penelitian menggunakan Rancangan Acak Lengkap (RAL) dengan empat faktor proposi penambahan tepung pisang klutuk yaitu $0 \%(\mathrm{~F} 0), 20 \%(\mathrm{~F} 1), 30 \%(\mathrm{~F} 2)$ dan $40 \%(\mathrm{~F} 3)$. Selain itu, semua perlakuan kecuali F0 (kontrol) disubtitusi juga dengan tepung tempe kedelai sebesar $5 \%$. Kandungan gizi biskuit terpilih berdasarkan pertimbangan mutu kimia dan organoleptik adalah F1 dengan kadar air 4,88\%, kadar abu 2,03\%, kadar protein 7,53\%, kadar lemak $28,12 \%$, serat kasar $1,87 \%$, karbohidrat $56,23 \%$, serat pangan $13,5 \%$, total pati $44,54 \%$, daya cerna pati $60,4 \%$. Nilai indeks glikemik biskuit tepung pisang klutuk adalah 36 dan termasuk rendah. Biskuit pisang klutuk dapat dijadikan salah satu alternatif pangan fungsional terutama bagi diabetic.

Kata kunci : diabetes, indeks glikemik rendah, pisang klutuk, pangan fungsional, serat pangan

\section{Abstract}

This research is aimed to produce low Glycemic Index (Gl) biscuit by substituting wheat flour with klutuk banana flour and tempe flour. Banana is known to have low GI (46-51). Soybean and its products are also known as potential sources of protein as well as having low Gl. Klutuk banana is selected due to its under-utilised usage in food production. A completely randomized design was applied by involving four factors of klutuk banana flours which were $0 \%(F 0), 20 \%$ (F1), 30\%(F2) and 40\%(F3). In addition, The treatments (F1-F3) also used 5 percent tempe flour. The results showed that panelists acceptance declined with increasing substitution of klutuk banana flour. Biscuit with substitution of $20 \%$ klutuk banana flour (F1) was then selected as the most potential formulation based on its physico-chemical properties, nutritional qualities and sensory evaluation. The selected (F1) klutuk banana biscuit contained $4.88 \%$ moisture, $2.03 \%$ ash, $7.53 \%$ protein, $28.12 \%$ fat, $1.87 \%$ crude fiber, $56.23 \%$ carbohydrates, $13.5 \%$ dietary fiber, $44.54 \%$ total starch, $60.4 \%$ starch digestibility. Glycemic index of the selected biscuit was 36 (low GI). Klutuk banana biscuits may be used as an alternative functional food, especially for diabetic.

\section{Keyword : diabetes, dietary fiber, functional food, klutuk banana, low glycemic index}

\section{Pendahuluan}

Diabetes adalah suatu penyakit dimana pankreas tidak dapat menghasilkan insulin (hormon pengatur glukosa darah) atau terjadinya resistansi insulin sehingga menyebabkan glukosa darah meningkat saat diperiksa. Resistensi insulin banyak ditemui bersamaan dengan resiko kardiovaskular lainnya, seperti hipertensi, dislipidemia, yang bersifat aterogenik (Rohman, 2007). Penyakit Diabetes Melitus (DM) saat ini menjadi masalah paling umum di dunia, baik di negara maju maupun berkembang (PERKENI, 2006). WHO memperkirakan pada tahun 2025, Indonesia akan menempati peringkat lima di dunia dengan jumlah penderita DM sebanyak 12.4 juta jiwa (Suyono, 2006). Persatuan Diabetes Indonesia (2011) melaporkan bahwa jumlah penderita DM di Jawa Timur sebesar 6\% dari total jumlah penduduk sebanyak 37.476 .757 orang (Sensus Penduduk, 2010). Prevalensi DM meningkat dari tahun 2007 sampai tahun 2013 hampir di semua provinsi di Indonesia (Riskesdas, 2013).

Terapi bagi penderita DM dilakukan dengan tujuan memelihara dan menjaga kesehatan secara optimal agar dapat melakukan aktivitas seperti biasanya. Waspadji (2002) menjelaskan bahwa alternatif lain yang kemudian menjadi pilihan adalah pengaturan pola makan yang sehat untuk menekan peningkatan kadar glukosa darah. Konsep Indeks Glikemik (IG) merupakan pendekatan untuk memilih pangan yang baik, khususnya pangan sumber karbohidrat. Konsep ini berguna untuk membina kesehatan, mencegah obesitas, memilih pangan untuk berolahraga, dan mengurangi resiko menderita penyakit degeneratif. Lebih lanjut Rimbawan dan Siagian (2004) mengatakan bahwa konsep IG menekankan pada pentingnya mengenal pangan sumber karbohidrat berdasarkan kecepatannya meningkatkan kadar glukosa darah. Pangan yang 
memiliki IG tinggi akan meningkatkan kadar glukosa darah dengan cepat, demikian pula sebaliknya.

Salah satu bahan pangan lokal yang dapat digunakan sebagai pengganti terigu dan memiliki IG rendah sebesar 46-51 adalah pisang. Nilai IG tersebut lebih rendah dibandingkan dengan ubi jalar ungu (54 68) (Rimbawan dan Siagian, 2004). Potensi Indonesia sangat besar untuk produksi pisang karena dari tahun ke tahun mengalami peningkatan misalnya tahun 2013 hasilnya 6.279.279 dan tahun 2014 mencapai 7.008. 407 (Kementan, 2014). Pisang klutuk termasuk pisang yang kurang dimanfaatkan. Pemanfaatannya masih terbatas pada penepungan, kripik bahkan hanya dijadikan bahan campuran makanan rujak (Margono, 2000). Pisang klutuk memiliki kandungan tinggi serat dan sumber fenol. Pada pisang klutuk kandungan serat kasar sebesar $6,9 \%$ (Endra, 2006). Makanan dengan kadar serat kasat tinggi cenderung meningkatkan bobot feses, menurunkan waktu transit di dalam saluran cerna, dan serat pangan yang dapat mengontrol metabolisme glukosa dan lipid (Almatsier, 2004).

Berdasarkan kenyataan tersebut, perlu adanya modifikasi produk makanan yang berbahan baku dengan IG rendah dimana makanan tersebut tetap mampu memberikan kontribusi kecukupan gizi bagi penderita DM. Salah satu makanan yang disukai oleh hampir semua tingkat umur adalah biskuit. Produk biskuit bermacam-macam bentuk salah satu bentuknya adalah Cookies. Biskuit dapat dijadikan sebagai pangan fungsional apabila biskuit tersebut memiliki sifat fungsional bagi kesehatan, diantaranya dapat mengontrol kadar glukosa darah dan memiliki indeks glikemik yang rendah. Sifat fungsional tersebut dapat diperoleh melalui perubahan ingredient utama yaitu penggantian terigu dengan bahan pangan lain yang memiliki kadar serat lebih tinggi dan IG yang relatif rendah. Biskuit merupakan salah satu produk makanan yang mulai dikembangkan sebagai makanan selingan penyandang DM. Pola makan penyandang DM dengan porsi kecil dan sering, sehingga selain makanan utama juga dibutuhkan makanan selingan untuk mencukupi kebutuhan gizi serta membantu mengendalikan glukosa darah (Franz, 2012). Pangan berbasis kedelai juga diketahui mempunyai kadar protein relatif tinggi dan nilai IG yangan relatif rendah. Oleh karena itu, penambahan tepung tempe pada pembuatan biskuit diharapkan dapat membantu menurunkan nilai IG pangan.

Berdasarkan hal tersebut, maka perlu adanya penelitian tentang formulasi pisang klutuk yang sudah menjadi tepung dalam rangka pembuatan biskuit yang rendah indeks glikemik. Diharapkan biskuit tersebut dapat menjadi salah satu pangan alternatif dan fungsional food bagi penderita diabetes sekaligus dalam rangka diversifikasi pangan.

\section{Materi dan Metode}

Bahan utama yang digunakan yaitu pisang klutuk yang diperoleh dari petani yang memiliki pekarangan/tanaman pisang klutuk dan pasar tradisional Desa Semanding, Kecamatan Kabuh, Kabupaten Jombang - Jawa Timur. Tempe yang digunakan berasal dari Sanan, Malang. Bahan-bahan untuk membuat biskuit, yaitu tepung terigu segitiga biru, sorbitol, susu skim, margarin, kuning telur, garam, dan soda kue. Bahan-bahan untuk analisis yaitu $\mathrm{K}_{2} \mathrm{SO}_{4}, \mathrm{HgO}, \mathrm{H}_{2} \mathrm{SO}_{4}$ pekat, $\mathrm{NaOH}, \mathrm{H}_{2} \mathrm{BO}_{3}$, indikator campuran metil redmetilen blue, $\mathrm{HCl}$, heksana, glukosa murni, air destilata, etanol $95 \%$, larutan asetat $1 \mathrm{~N}$, larutan iod, buffer fosfat $\mathrm{pH} 6$ dan $\mathrm{pH} 7$, buffer asetat $\mathrm{pH} 4.75$ dan bahan- bahan untuk analisis proksimat.

Metode yang digunakan dalam penelitian ini adalah analisis kimia yang dilakukan meliputi: Kadar Air (AOAC, 2005), Kadar Abu Metode Gravimetri (AOAC, 2005), Kadar Protein metode mikro kjeldahl (AOAC, 2005), Kadar Lemak Metode Soxhlet (AOAC, 2005), Kadar Serat Pangan Metode Enzimatis (AOAC, 1995), Kadar Serat Kasar (AOAC, 2005), Kadar Karbohidrat By Different (AOAC, 2005), Total Pati (Apriyantono et al, 1989, dengan modifikasi), daya cerna pati in vitro (Muchtadi et al, 1992), Uji indeks Glikemik (Jenkins et al, 2002).

Penelitian pendahuluan dimulai pembuatan tepung pisang klutuk dan tepung tempe kedelai. Tahap pembuatan tepung pisang klutuk adalah pisang klutuk dikupas dari kulitnya. Pisang diiris tipis dengan ketebalan $30 \times 30 \mathrm{~mm}$ kemudian direndam dengan bahan perlakuan (air/larutan $\mathrm{NaCl}$ ) selama 30 menit. dan dikeringkan pada suhu $80^{\circ} \mathrm{C}$ selama 10 jam. Setelah kering, pisang digiling dan diayak menggunakan ayakan tepung 35 mesh (Musita, 2014). Tahap pembuatan tepung tempe dimulai dari tempe segar yang dikukus selama 15 menit kemudian diiris tipis dengan ukuran $5 \mathrm{x}$ $5 \times 0,5 \mathrm{~cm}$, kemudian dikeringkan pada suhu $70^{\circ} \mathrm{C}$ selama 10 jam. Selanjutnya tempe digiling dan diayak menggunakan ayakan tepung 35 mesh. Metode ini adalah modifikasi dari Musita (2014).

Penelitian utama meliputi formulasi biskuit, analisis kimia dan analisis indeks glikemik. Resep formulasi "BATIK" merupakan hasil modifikasi dari Seprina (2010). Formula tersebut disajikan pada Tabel 1. Adapun skema proses pembuatan biskuit adalah margarin, gula, garam dan bahan pengembang dicampur sampai terbentuk krim homogen dengan menggunakan mixer. Selanjutnya, ditambahkan telur dan dikocok dengan kecepatan rendah dan selama pembentukan krim dan ditambahkan susu skim. Pada tahap akhir ditambahkan tepung terigu dan diaduk dengan tangan kemudian tepung pisang klutuk sampai tercampur halus kemudian ditambahkan tepung tempe kedelai. Pengadukan dilakukan sampai terbentuk adonan yang mengembang dan mudah dibentuk (kalis). Biskuit dicetak sesuai dengan selera (berat 7-8 gram) dengan ketebalan $50 \mathrm{~mm}$. Biskuit dioven pada suhu $160^{\circ} \mathrm{C}$ selama $20-30$ menit. Metode ini adalah modifikasi dari Faridah (2008)

\section{Analisis dan Pengolahan Data}

Rancangan percobaan yang digunakan pada penelitian ini adalah Rancangan Acak Lengkap (RAL). Faktor yang digunakan dalam penelitian ini yaitu subtitusi tepung pisang klutuk dengan tingkatan proporsi yang berbeda setiap taraf perlakuan. Selain itu di 
Tabel 1 Formulasi "Batik" biskuit tepung pisang klutuk dan tepung tempe kedelai

\begin{tabular}{lcccc}
\hline Formulasi "BATIK" (biskuit tepung & F0/ Kontrol $(\mathrm{g})$ & $\mathrm{F} 1(\mathrm{~g})$ & $\mathrm{F} 2(\mathrm{~g})$ & $\mathrm{F3}(\mathrm{g})$ \\
pisang klutuk dan tepung tempe kedelai) & $(100: 0: 0)$ & $(75: 20: 5)$ & $(65: 30: 5)$ & $(55: 40: 5)$ \\
\hline Tepung terigu & 13 & 96 & 82,5 & 70,5 \\
Tepung pisang klutuk & 0 & 26.5 & 40 & 52 \\
Tepung tempe kedelai & 0 & 7.5 & 7.5 & 7.5 \\
Susu skim & 10 & 10 & 10 & 10 \\
Sorbitol & 5 & 5 & 5 & 5 \\
Margarin & 80 & 80 & 80 & 80 \\
Maizena & 10 & 10 & 10 & 10 \\
Kuning Telur & 10 & 10 & 10 & 10 \\
\hline
\end{tabular}

Tabel 2 Hasil analisis proksimat biskuit

\begin{tabular}{lrrrr}
\multicolumn{1}{c}{ Komposisi } & \multicolumn{1}{c}{ F0 } & \multicolumn{1}{c}{ F1 } & \multicolumn{1}{c}{ F2 } \\
\hline Kadar Air (\%bb) \pm SD & $3,39^{\mathrm{a}} \pm 0.02$ & $4,88^{\mathrm{b}} \pm 0.28$ & $4,06^{\mathrm{b}} \pm 0.64$ & $7,06^{\mathrm{c}} \pm 0.77$ \\
Kadar Abu (\%bb) \pm SD & $1,75^{\mathrm{a}} \pm 0.54$ & $2,03^{\mathrm{a}} \pm 0.03$ & $2,25^{\mathrm{a}} \pm 0.02$ & $2,44^{\mathrm{a}} \pm 0.04$ \\
Kadar Protein (\%bb) \pm SD & $7,49^{\mathrm{a}} \pm 0.14$ & $7,53^{\mathrm{a}} \pm 0.07$ & $7,20^{\mathrm{b}} \pm 0.10$ & $7,09^{\mathrm{b}} \pm 0.06$ \\
Kadar Lemak (\%bb) \pm SD & $27,58^{\mathrm{a}} \pm 0.39$ & $26,84^{\mathrm{a}} \pm 1.41$ & $27,88^{\mathrm{a}} \pm 1.11$ & $27,61^{\mathrm{a}} \pm 1.22$ \\
Kadar Karbohidrat(\%bb) \pm SD & $58,88^{\mathrm{a}} \pm 0.15$ & $56,87^{\mathrm{a}} \pm 1.29$ & $56,14^{\mathrm{a}} \pm 0.71$ & $52,66^{\mathrm{b}} \pm 1.97$ \\
Kadar Serat kasar $(\% b b) \pm$ SD & $1,23^{\mathrm{a}} \pm 0.35$ & $1,87^{\mathrm{b}} \pm 0.06$ & $2,48^{\mathrm{c}} \pm 0.35$ & $3,17^{\mathrm{d}} \pm 0.12$ \\
\hline
\end{tabular}

Keterangan : Nilai yang diikuti dengan huruf yang sama menunjukkan hasil yang tidak berbeda menurut uji lanjut LSD pada taraf $5 \%$.

subtitusi tepung tempe pada formula 1 sampai 3. Pengolahan data dilakukan dengan menggunakan software Microsoft Excel 2007 dan SPSS 16. Hasil penilaian mutu kimia dianalisa menggunakan Analysis of Variance (ANOVA) program SPSS 16, jika ada pengaruh nyata maka dilanjutkan dengan uji Least Significant Difference (LSD) (Setyaningsih et al, 2010).

\section{Hasil dan Pembahasan}

Formulasi "BATIK"

Formulasi dilakukan untuk mendapatkan komposisi yang sesuai dengan perbandingan subtitusi tepung pisang klutuk dan tepung tempe. Tujuan dari formulasi adalah menghasilkan produk yang sesuai SNI 01-2973-2011 tentang syarat mutu biskuit berupa cookies dan produk mampu memberikan manfaat lebih bagi konsumen. Hasil formulasi dengan komposisi bahan yang disajikan pada Tabel 1 kemudian dianalisis kadar zat gizi proksimatnya.

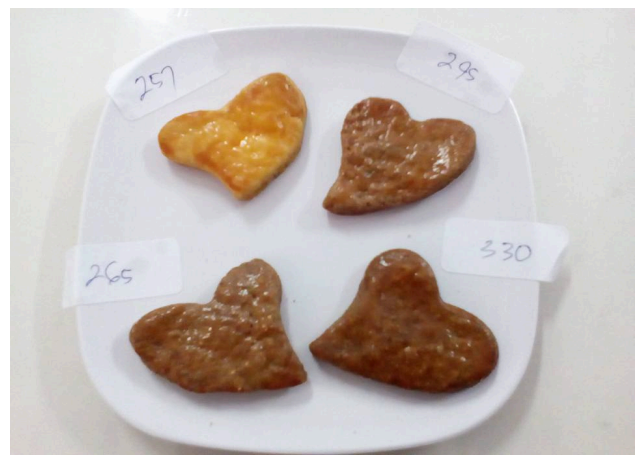

Gambar 1 Biskuit Hasil Formulasi

\section{Karakteristik Biskuit}

Karakteristik yang dinilai berdasarkan SNI 2973: 2011 tentang syarat mutu biskuit adalah kadar air dan kadar protein. Selain syarat mutu tersebut, pada penelitian ini dilakukan pula penilaian mutu secara kimia (serat pangan, total pati, daya cerna pati, kadar lemak, serat kasar, energi, karbohidrat) dan indeks glikemik.
Penilaian mutu secara kompleks diharapkan mampu meningkatkan kualitas produk biskuit yang dihasilkan. Hasil analisis disajikan pada Tabel 2.

\section{Kadar Air}

Kadar air berhubungan dengan tekstur yang dihasilkan pada produk biskuit pisang klutuk. Kadar air biskuit pisang klutuk mengalami peningkatan pada setiap taraf perlakuan (F0 - F3). Pada F0-F2 kadar air biskuit dibawah $5 \%$ sehingga memenuhi standar maksimum kadar air SNI 2973 : 2011 yaitu $5 \mathrm{~g} / 100 \mathrm{~g}$. Pada taraf perlakuan F3 tidak memenuhi standar kadar air yang ditentukan oleh SNI karena kadar airnya sebesar 7,06 g/100 g. Ighfar (2012) menuliskan bahwa kadar air pada produk biskuit perlu dibatasi $5-10 \%$ untuk menjaga tekstur biskuit agar tetap renyah. Hal tersebut menunjukkan bahwa biskuit pisang klutuk tiap taraf perlakuan masih memenuhi syarat kadar air untuk menghasilkan produk biskuit dengan tekstur yang renyah

Hasil analisis statistik Oneway Anova menunjukkan bahwa subtitusi tepung pisang klutuk dan tepung tempe memberikan pengaruh yang signifikan ( $p$ $=0,047$ ) terhadap kadar air biskuit pisang klutuk. Lebih lanjut, analisis Least Significant Difference (LSD) menunjukkan bahwa subtitusi tepung pisang klutuk $20 \%$ $(\mathrm{F} 1)$ telah memberikan pengaruh peningkatan kadar air yang signifikan sampai dengan subtitusi sebanyak $40 \%$ (F3). Peningkatan kadar air taraf perlakuan (F3) dipengaruhi oleh penambahan air yang lebih banyak dibandingkan perlakuan yang lain (F0-F2). Hal tersebut dilakukan karena adonan F3 masih terlalu keras/tidak dapat dioleni sehingga perlu penambahan air yang lebih banyak dibandingkan perlakuan yang lain dengan suhu dan waktu pemanggangan yang sama.

Air dalam pengolahan biskuit berfungsi untuk mengikat dan mencampurkan bahan-bahan subtitusi sehingga terbentuk adonan yang kalis dan dapat dicetak. Sebagaimana dijelaskan Soenaryo (1985) 
bahwa kegunaan air pada pengolahan produk pangan adalah untuk media reaksi antara glutein dengan karbohidrat, larutan garam dan membentuk sifat kenyal dari glutein. Meskipun telah diupayakan setiap taraf perlakuan mendapatkan perlakuan yang sama, antara lain penambahan garam, susu, margarin, ketebalan adonan, suhu pengovenan, lama pengovenan serta pengemasan.

\section{Kadar Abu}

Kadar air biskuit pisang klutuk mengalami peningkatan pada setiap taraf perlakuan (F0 - F3). Hal tersebut menunjukkan bahwa peningkatan subtitusi tepung pisang klutuk akan meningkatkan kadar abu biskuit. Tabel 4 menunjukkan bahwa kadar abu terendah adalah F0 (1,75\%) dan tertinggi adalah F3 (2,44\%). Hasil analisis statistik Oneway Anova menunjukkan bahwa subtitusi tepung pisang klutuk dan tepung tempe memberikan pengaruh yang tidak signifikan $(p=0,068)$ terhadap kadar abu biskuit pisang klutuk. Tidak ada perbedaan antara perlakuan F0 - F3 dimana subtitusi tepung pisang klutuk dan tepung tempe tidak mempengaruhi kadar abu biskuit pisang klutuk. Kandungan abu dari suatu bahan pangan menunjukkan residu bahan anorganik yang tersisa bahan organik didekstruksi (Sudarmadji, 2003).

\section{Kadar Protein}

Kadar protein biskuit pisang klutuk mengalami penurunan pada setiap taraf perlakuan (F0 - F3). Kadar protein tertinggi adalah $\mathrm{F} 1$ sebesar $7,53 \%$ dan terendah F3 $(7,09 \%)$ telah memenuhi standar minimum SNI 2973:2011, yaitu $5 \mathrm{~g} / 100 \mathrm{~g}$. Hasil analisis statistik Oneway Anova menunjukkan bahwa subtitusi tepung pisang klutuk dan tepung tempe memberikan pengaruh yang signifikan $(p=0,043)$ terhadap kadar protein biskuit pisang klutuk. Lebih lanjut, analisis Least Significant Difference (LSD) menunjukkan bahwa subtitusi tepung pisang klutuk 20\% (F1) masih belum menunjukkan hasil yang berbeda nyata. Perlakuan F0 dan F1 mengandung kadar protein yang hampir sama sedangkan hasil berbeda mulai ditunjukkan pada perlakuan F2 (30\%) subtitusi tepung pisang klutuk. Kontribusi protein biskuit pisang klutuk bervariasi karena berasal dari tepung terigu, tepung pisang klutuk, susu skim dan tepung tempe kedelai. Tepung tempe mengandung protein lebih besar (40\%) daripada tepung pisang klutuk yang hanya 5,3\% (Tabel 2). Sarwono (2003) menyebutkan bahwa kadar protein pada tepung tempe sebesar $43,31 \%$.

Kadar protein biskuit pisang klutuk juga dipengaruhi oleh penambahan kuning telur. Muchtadi (2010) menyebutkan bahwa kandungan protein pada kuning telur lebih tinggi dibandingkan dengan putih telur, yaitu masing-masing 16,1 g/100g dan 10,6 g/100 g. Selain itu, penggunaan kuning telur pada adonan biskuit pisang klutuk akan menghasilkan biskuit kering yang lebih renyah daripada jika menggunakan seluruh bagian telur. Kuning telur juga akan menambahkan warna pada hasil akhir produk cookies (U. S Wheat Associates, 1981). Pada pengolahan biskuit pisang klutuk, penambahan telur ayam bagian kuning hanya 20 gram atau 1 butir, lebih rendah daripada pengolahan biskuit subtitusi residu ekstraksi pati jagung (Zea mayz L.) (Seprina, 2010).

\section{Kadar Lemak}

Kadar lemak biskuit pisang klutuk relatif sama pada tiap taraf perlakuan. Kadar lemak tertinggi adalah F2 sebesar $27,88 \%$ dan terendah adalah F1 (26,84\%). Hal tersebut disebabkan oleh bahan utama penyusun biskuit yang rendah lemak yaitu tepung pisang klutuk dan tepung terigu masing-masing sebesar $0,9 \mathrm{~g} / 100 \mathrm{~g}$ (Tabel 2) dan $1 \mathrm{~g} / 100 \mathrm{~g}$ (Bogasari, 2011). Bahan yang berkontribusi terhadap kadar lemak biskuit pisang klutuk adalah margarin. Jumlah penambahan margarin yang sama pada tiap taraf perlakuan menghasilkan kadar lemak yang relatif sama pada tiap taraf perlakuan. Hasil analisis statistik Oneway Anova menunjukkan bahwa subtitusi tepung pisang klutuk dan tepung tempe memberikan pengaruh yang tidak signifikan $(p=0,468)$ terhadap kadar lemak biskuit pisang klutuk.

Kontribusi lemak pada perlakuan FO-F3 juga berasal dari tepung tempe. Kadar lemak tepung tempe cukup tinggi yaitu sebesar $26,58 \%$ (Tabel 3). Cahyadi (2006) menyebutkan bahwa selain sebagai sumber protein, tepung tempe kedelai juga merupakan sumber lemak. Tepung tempe kedelai mengandung lemak sebesar $22,2 \%$. Sebagian besar lemak yang ada pada tepung tempe kedelai merupakan lemak tak jenuh yaitu asam linoleat yang merupakan asam lemak utama pada tempe yang secara spesifik bersifat meningkatkan HDL dan menurunkan LDL. Lebih lanjut Mann (2007) menjelaskan bahwa jika konsumsi energi dari lemak jenuh diganti oleh asam linoleat, maka secara bermakna akan menurunkan kolesterol darah sehingga tidak terjadi hiperlipidemia akibat hiperglikemik

\section{Kadar Karbohidrat}

Kadar karbohidrat biskuit pisang klutuk mengalami penurunan pada setiap taraf perlakuan (FO F3). Kadar terendah sebesar $52,66 \%$ (F3) dan kadar tertinggi sebesar $58,88 \%$ (F0). Kadar karbohidrat biskuit pisang klutuk relatif menurun dengan peningkatan substitusi tepung pisang klutuk dan pengurangan penggunaan terigu. Hal ini disebabkan kadar karbohidrat pada tepung pisang klutuk sebesar $70 \mathrm{~g} / 100 \mathrm{~g}$ (Tabel 2) lebih rendah daripada tepung terigu yaitu $73 \mathrm{~g} / 100 \mathrm{~g}$ (Bogasari, 2011). Hasil analisis statistik Oneway Anova menunjukkan bahwa subtitusi tepung pisang klutuk dan tepung tempe memberikan pengaruh yang signifikan ( $p$ $=0,031$ ) terhadap kadar karbohidrat biskuit pisang klutuk. Lebih lanjut, analisis Least Significant Difference (LSD) menunjukkan bahwa subtitusi tepung pisang klutuk 20\% - 30\% (F1 dan F2) masih belum menunjukkan hasil yang berbeda nyata dengan F0. Namun subtitusi tepung pisang klutuk sebesar $40 \%$ memberikan hasil yang signifikan/ berbeda terhadap kadar karbohidrat biskuit.

Menurunnya kadar karbohidrat biskuit pisang klutuk setiap peningkatan subtitusi tepung pisang klutuk merupakan keunggulan tersendiri apabila dikonsumsi penderita DM. Bagi penderita DM harus membatasi 
konsumsi karbohidrat jenis monosakarida karena meningkatkan kadar glukosa darah secara cepat. Berbeda dengan karbohidrat jenis polisakarida termasuk oligosakarida yang banyak terdapat pada buah-buahan salah satunya pisang. Jenis karbohidrat polisakarida (kompleks) akan merespon glukosa secara lambat sehingga tidak terjadi peningkatan kadar glukosa darah secara cepat. Fungsi utama karbohidrat yaitu sumber energi dimana satu gram karbohidrat setara dengan 4 Kalori (Winarno, 2004). Bahan pangan yang mengandung karbohidrat oligosakarida (kompleks) akan melalui beberapa tahap pemecahan dalam proses metabolisme sebelum menghasilkan glukosa sehingga proses metabolisme relatif lebih lama. Makanan yang mengandung karbohidrat kompleks baik bagi penderita DM karena tidak meningkatkan kadar glukosa darah secara cepat.

\section{Kadar Serat Kasar}

Kadar serat kasar biskuit pisang klutuk mengalami peningkatan pada setiap taraf perlakuan (F0 - F3). Kadar serat kasar biskuit pisang klutuk berkisar antara $1,23 \%$ (F0) - 3,17\% (F3). Semakin tinggi subtitusi tepung pisang klutuk maka kadar serat kasar biskuit pisang klutuk akan meningkat. Hasil analisis statistik Oneway Anova menunjukkan bahwa subtitusi tepung pisang klutuk dan tepung tempe memberikan pengaruh yang signifikan $(p=0,001)$ terhadap kadar serat kasar biskuit pisang klutuk. Lebih lanjut, analisis Least Significant Difference (LSD) menunjukkan bahwa subtitusi tepung pisang klutuk 20\% (F1) sudah menunjukkan hasil yang berbeda nyata dengan FO. Semakin tinggi subtitusi tepung pisang klutuk maka kadar serat kasar akan semakin tinggi/ berbeda nyata.

Kadar serat kasar tepung pisang klutuk sebesar $5,56 \%$ (Tabel 2). Selain itu, tepung tempe kedelai juga merupakan sumber serat. Tepung tempe kedelai memiliki serat yang merupakan karbohidrat atau polisakarida sebanyak $7,2 \mathrm{~g} / 100 \mathrm{~g}$ yang tidak dapat dicerna oleh tubuh. Kadar bahan-bahan tersebut lebih tinggi dibandingkan tepung terigu yang hanya mengandung 0,3\% serat kasar (Mahmud, 2009).

Tabel 3 Hasil analisis mutu organoleptik

\begin{tabular}{ccccc}
\hline \multirow{2}{*}{ Perlakuan } & \multicolumn{4}{c}{ Atribut organoleptik } \\
\cline { 2 - 5 } & Rasa & Warna & Aroma & Tekstur \\
\hline F0 & $5,73^{\mathrm{a}}$ & $6,17 \mathrm{a}$ & $6,00^{\mathrm{a}}$ & $5,52^{\mathrm{a}}$ \\
F1 & $4,30^{\mathrm{ab}}$ & $4,20^{\mathrm{ab}}$ & $4,45^{\mathrm{ab}}$ & $4,58^{\mathrm{ab}}$ \\
F2 & $3,67^{\mathrm{b}}$ & $3,80^{\mathrm{b}}$ & $3,81^{\mathrm{b}}$ & $4,35^{\mathrm{ab}}$ \\
F3 & $3,63^{\mathrm{b}}$ & $3,67^{\mathrm{b}}$ & $3,68^{\mathrm{b}}$ & $3,45^{\mathrm{b}}$ \\
\hline
\end{tabular}

Keterangan : berdasarkan uji Kruskal Wallis ( $p<0.05$ ) sehingga dilakukan uji lanjut. Nilai yang diikuti dengan huruf yang sama pada setiap kolom menunjukkan nilai yang tidak berbeda nyata (uji lanjut Man Whitney $a=5 \%$ )

\section{Mutu Organoleptik}

Uji orgaloleptik terhadap biskuit pisang klutuk dilakukan untuk mengetahui daya terima terhadap beberapa atribut sensori biskuit seperti warna, aroma, rasa dan tekstur yang hasilnya dibandingkan antar tiap perlakuan. Uji organoleptik produk adalah untuk memberikan pendapat yang nyata mengenai disukai atau tidak disukainya suatu produk (Hariom et al, 2006).

Tabel 3 menunjukkan bahwa semakin tinggi subtitusi tepung pisang klutuk maka tingkat kesukaan panelis semakin menurun. Hal tersebut sesuai dengan penelitian Damayanti (2005) yang menyebutkan bahwa penambahan bahan sumber serat pada jajanan pasar akan menurunkan tingkat penerimaan panelis baik aroma, rasa, tekstur maupun warna. Berdasarkan pertimbangan menggunakan metode pembobotan eksponensial (MPE) (Setyaningsih, 2010) maka perlakuan 1 dipilih sebagai perlakuan terbaik. Pembobotan dipilih berdasarkan hasil mutu kimia biskuit dan rata-rata nilai organeptik dengan perbandingan 50 : 50.

Hasil analisis mutu kimia dan indeks glikemik biskuit formulasi dari penelitian ini disajikan pada Tabel 4.

Tabel 4 Hasil Analisis Formula Terbaik

\begin{tabular}{ll}
\hline Jenis Analisis & Hasil Analisis F1 (20\%) \\
\hline Total pati (\%) & 44,54 \\
Daya cerna pati (\%) & 60,4 \\
Serat pangan (\%) & 13,55 \\
Indeks Glikemik & 36,17 \\
\hline
\end{tabular}

Total Pati

Total pati biskuit subtitusi pisang klutuk sebesar $44,54 \%$. Pisang klutuk merupakan jenis pisang yang memiliki pati resisten 1 cukup tinggi yaitu 39,35\% (Musita, 2008). Pati sresisten (RS) sangat bermanfaat bagi penyandang DM. Hal tersebut dikarenakan pati resisten mampu menahan sistem pencernaan sehingga lebih lama dicerna. RS menurunkan efek glikemik serta sensitif terhadap hormon insulin sehingga dapat menurunkan potensi diabetes tipe 2 (Herawati, 2010).

\section{Daya Cerna Pati}

Daya cerna pati biskuit pisang klutuk sebesar $60,4 \%$. Hidrolisis pati resisten oleh enzim pencernaan umumnya membutuhkan waktu yang lebih lama sehingga proses produksi glukosa menjadi lebih lambat. Hal ini selanjutnya berkorelasi dengan respons glikemik plasma (Raben et al, 1994). Secara tidak langsung, RS mempunyai nilai fungsional bagi penyandang diabetes.

\section{Serat Pangan}

Kadar serat pangan biskuit yang dihasilkan lebih tinggi dibandingkan dengan kadar serat pangan produk biskuit komersial pada umumnya. Diet cukup serat menyebabkan terjadinya kompleks karbohidrat dan serat, sehingga daya cerna karbohidrat berkurang. Keadaan tersebut mampu meredam kenaikan glukosa darah dan menjadikannya tetap terkontrol (Santoso, 2011).

\section{Analisis Indeks Glikemik}

Hasil penentuan IG biskuit yang diperoleh dari penelitian ini disajikan pada Tabel 5 dan Gambar 2. 
Tabel 5 Perhitungan nilai indeks glikemik responden

\begin{tabular}{ll}
\hline Responden & Nilai IG \\
\hline 1 & 31,97 \\
2 & 26,61 \\
3 & 35,65 \\
4 & 41,12 \\
5 & 30,09 \\
6 & 42,51 \\
7 & 42,47 \\
8 & 36,71 \\
9 & 38,67 \\
10 & 35,96 \\
\hline Rata-rata & 36,18 \\
\hline Standar Deviasi & 5,35
\end{tabular}

Tabel 5 menunjukkan bahwa nilai indeks glikemik biskuit pisang klutuk sebesar 36,8 dan termasuk dalam kategori rendah ( Low GI <55). Pangan IG rendah akan dicerna dan diubah menjadi glukosa secara bertahap dan perlahan-lahan sehingga puncak kadar glukosa darah juga akan rendah, berarti fluktuasi peningkatan kadar gula relatif pendek. Hal ini sangat penting bagi penderita diabetes dalam mengendalikan kadar glukosa darah. Informasi IG pangan dapat membantu penderita DM dalam memilih makanan yang tidak meningkatkan kadar glukosa darah secara drastis sehingga kadar glukosa darah dapat dikontrol pada tingkat yang aman. Pangan IG rendah membantu orang untuk mengendalikan rasa lapar, selera makan, dan kadar glukosa darah (Widowati, 2007).

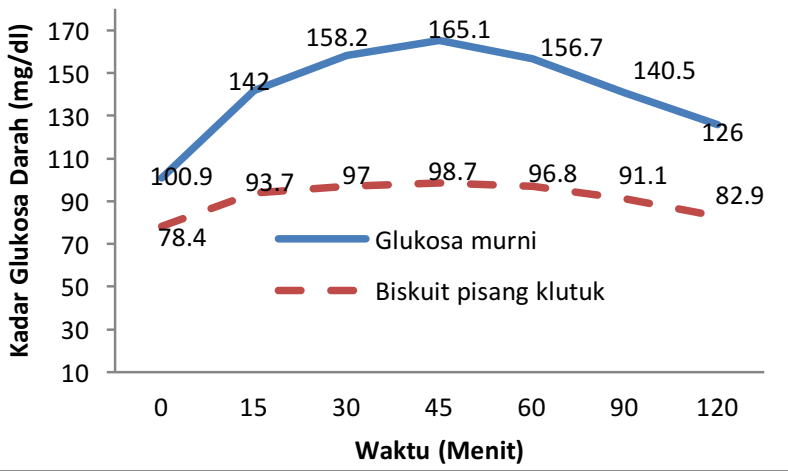

Gambar 2. Kurva Perubahan Kadar Glukosa Darah dan Pangan Uji

\section{Kesimpulan}

Penggunaan 5\% tepung tempe dapat mempertahankan kadar protein biskuit akibat pengurangan penggunaan tepung terigu. Formulasi pengembangan biskuit subtitusi pisang klutuk sebesar 0\% (F0), 20\% (F1), 30\% (F2) dan 40\% (F3) menurunkan penerimaan panelis terhadap biskuit yang dihasilkan dari tingkatan suka menjadi agak tidak suka. Pemilihan perlakuan terbaik (F1) memiliki skor rata-rata penerimaan panelis biasa sampai suka dan kategori IG rendah yaitu 36 . Kandungan gizi biskuit pisang klutuk terpilih adalah kadar air 4,88\%, kadar abu 2,03\%, kadar protein $7,53 \%$, kadar lemak $26,84 \%$, serat kasar $1,87 \%$, karbohidrat $56,87 \%$, serat pangan $13,5 \%$, total pati $44,54 \%$, daya cerna pati $60,4 \%$. Biskuit pisang klutuk dapat dijadikan salah satu alternatif pangan fungsional terutama bagi penyandang diabetes mellitus.

\section{Saran}

Biskuit pisang klutuk masih memiliki skor penerimaan panelis yang agak rendah sehingga perlu adanya reformulasi ulang untuk lebih meningkatkan daya terima panelis (warna, tekstur, aroma dan rasa) menjadi sangat suka. Perlu adanya penelitian lanjutan untuk mengolah tepung pisang klutuk menjadi produk lain dalam rangka peningkatan diversifikasi pangan dan meningkatkan nilai tambah pisang klutuk seperti bolu, cake atau produk bakery lainnya.

\section{Ucapan Terima Kasih}

Terima kasih ditujukan pada PT Indofood Sukses Makmur Tbk. yang telah memberikan dana penelitian dalam program Indofood Riset Nugraha Periode 20152016.

\section{Daftar Pustaka}

Badan Standardisasi Nasional. 2011. Mutu dan Cara Uji Biskuit (SNI 01-2973-2011). Jakarta (ID) : BSN.

Almatsier S. 2004. Prinsip Dasar Ilmu Gizi. Jakarta (ID) : Gramedia Pustaka Utama

AOAC. 2005. Official Method of Analysis of the Association of Official Analitycal Chemists. 18th ed. Maryland: AOAC International. William Harwitz (ed). United States of America.

Apriyantono A, Fardiaz D, Puspitasari NL, Yasni S, Budiyanto S. 1989. Petunjuk Laboratorium Analisis Pangan. Bogor (ID): IPB Press

BPS. 2010. Sensus Penduduk Indonesia. Jakarta (ID): BPS

Bogasari. 2011. Cake Making. Jakarta (ID) : Major Program Bogasari Baking Centre

Damayanti D.I. 2005. Pengaruh Jenis dan Proporsi Serat Cincau Dalam Tepung Terhadap Karakteristik Brownies fungsional. (Skripsi). Lampung: Unila.

Endra Y. 2006 . Analisis Proksimat dan Komposisi Asam Amino Buah Pisang Batu (Musa balbisiana Colla). Bogor (ID): Institut Pertanian Bogor.

Faridah DN, Kusnandar F, Herawati D, Kusumaningrum HD, Wulandari N, dan Indrasti D. 2008. Penuntun Praktikum Analisis Pangan. Departemen IImu dan Teknologi Pangan, IPB.

Franz M. 2012. Medical Nutrition Therapy for Diabetes Mellitus and Hypoglicemia of Nondiabetic Origin. In: Mahan LK, Escott-stump S, Janice LR, editors. Krause's Food, Nutrition, and Diet Therapy 13th Edition. Philadelphia: WB Saunders Company.. p. 675-708.

Hariom SBN, Prakash M, dan Bhat KK. 2006. Vanilla flavor evaluation by sensory and electronic nose techniques. Journal of Sensory Studies, 21, 228239.

Herawati H. 2011. Potensi Pengembangan Produk Pati Tahan Cerna sebagai Pangan Fungsional. Jurnal Litbang Pertanian. 30 (1).

Igfar A. 2012. Pengaruh Penambahan Tepung Labu Kuning (Cucurbita Moschata) Dan Tepung Terigu 
Terhadap Pembuatan Biskuit. Makassar. Universitas Hasanuddin.

Jenkins. D.J.A, C.W.C. Kendall, L.S.A. Augustin, S. Franceschi, M. Hamidi, A. Marchie, A.L. Jenkins and M. Axelsen. 2002. Glycemic index: overview of implications in health and disease. Am. J. Clin. Nutr. 76(1): 266S-273S.

Kementan. 2014. Total produksi pisang tahun 20132014. Jakarta (ID) :www. deptan.go.id

Mahmud et al. 2009. Tabel Komposisi Pangan Indonesia. Jakarta: Elex Media Komputindo.

Mann, Jim and A. Stewart Truswell (ed). 2007. Essentials of human nutrition (Third edition). London (UK): Oxford University Press.

Margono T. 2000. Anggur Buah Pisang Klutuk. Jakarta: Grasindo

Muchtadi D, Palupi NS, dan Astawan M. 1992. Metode Kimia, Biokimia, dan Biologi dalam Evaluasi Nilai Gizi. Pusat Antar Universitas Pangan dan Gizi.IPB, Bogor.

Muchtadi D. 2010. Kedelai Komponen untuk Kesehatan. Bandung : Alfabeta. Hal 20-160

Musita. Nanti. 2008. Kajian dan Karakteristik Pati Resisten dari Beberapa Jenis Pisang. Tesis Pasca Sarjana Teknologi Agroindustri Unila. Lampung.

Musita. Nanti. 2014. Pemanfaatan Tepung Pisang Batu (Musa Balbisiana Colla) Pada Pembuatan Kue Brownies. Jurnal Riset Industri 2014; 8:3 hal 171178: Desember 2014

PERKENI. 2006, Konsensus Pengelolaan dan Pencegahan Diabetes Melitus Tipe 2 di Indonesia. Jakarta (ID) : PERKENI

PERKENI. 2011, Konsensus Pengelolaan dan Pencegahan Diabetes Melitus Tipe 2 di Indonesia. Jakarta (ID) : PERKENI

Raben A., Tagliabue, A., Christensen, N. J., Madsen, J.,Holst, J. J., And Astrup, A. 1994. Resistant Starch: The Effect On Postprandial Glycemia, Hormonal Response, And Obesity. Am. J. Clin.Nutr. 60:544

Rimbawan, dan A. Siagian. 2004. Indeks Glikemik Pangan, Cara Mudah Memilih Pangan yang Menyehatkan. Penebar Swadaya. Jakarta
Riskesdas. 2013. Laporan Hasil Riset Kesehatan Dasar. Jakarta: Badan Penelitian dan Pengembangan Kesehatan, Departemen Kesehatan, Republik Indonesia

Rohman M.S. 2007. Patogenesis dan Terapi Sindroma Metabolik. Jurnal Kardiologi Indonesia. J Kardiol Ind 2007; 28:160-168 ISSN 0126/3773

Santoso A. 2011. Serat Pangan (Dietary Fiber) dan Manfaatnya Bagi Kesehatan. Magistra No.75 th XXIII, ISSN 0215-9511

Sarwono B. 2003. Membuat Tempe Dan Oncom. Penebar Swadaya. Jakarta.

Seprina A. 2010. Kajian Substitusi Tepung Terigu dan Residu Ekstraksi Pati Jagung (Zea mayz L.) dalam Pembuatan Biskuit Berserat. (Skripsi) Universitas Lampung. Bandar Lampung

Setyaningsih D, Apriyantono A, Sari MP. 2010. Analisis Sensori untuk Industri Pangan dan Agro. Bogor: IPB Press.

Sudarmadji S., B. Haryono, dan Suhardi. 2003. Prosedur Analisa Bahan Makanan Pertanian. Liberty, Yogyakarta

Sunaryo E. 1985. Pengolahan Produk Serealia dan Bijibijian. Jurusan Teknologi Pertanian Institut Pertanian Bogor. Bogor. Dalam : Effri Welly. 2003. Pengaruh Proporsi Tepung Sukun ( Artocarpus communis) Terhadap Sifat Fisik, Kimia dan Organoleptik Biskuit. Skripsi Universitas Lampung. Bandar Lampung

Suyono S. DM di Indonesia. Buku Ajar Ilmu Penyakit Dalam Jilid III Edisi 4. Jakarta : Pusat Penerbit Departemen IImu Penyakit Dalam Fakultas Kedokteran Universitas Indonesia; 2006. Hal 1852-56.

Waspadji S, Suyono S, Sukardji K, Moenarko K. 2003 Hasil Penelitian Indeks Glikemik Berbagai Makanan Indonesia. Jakarta (ID) : Balai Penerbit Fakultas Kedokteran Universitas Indonesia

Widowati S. 2007. Sehat dengan Pangan Indeks Glikemik Rendah. Warta Penelitian dan Pengembangan Pertanian. Bogor (ID). Vol 29. No. 3.

Winarno FG. 2008. Kimia Pangan dan Gizi. Jakarta : PT Gramedia Pustaka Utama 